\title{
STUDI KOMPERATIF KUALITAS PELAYANAN BPJS PADA PASIEN RAWAT INAP KELAS III DI RUMAH SAKIT KABUPATEN BULELENG (RUMAH SAKIT UMUM DAERAH KABUPATEN BULELENG DAN RUMAH SAKIT KERTA USADHA)
}

\author{
Komang Adi Suardana ${ }^{1}$, Anjuman Zukhri ${ }^{2}$, Kadek Rai Suwena ${ }^{3}$ \\ Jurusan Pendidikan Ekonomi \\ Universitas Pendidikan Ganesha \\ Singaraja, Indonesia
e-mail : wida123.kw@gmail.com¹, anjumanzukhri09@gmail.com², kadek_suwena@yahoo.co.id ${ }^{3}$

\begin{abstract}
Abstrak
Penelitian ini bertujuan untuk mengetahui kualitas pelayanan BPJS pada pasien rawat inap kelas III di Rumah Sakit Umum Daerah Kabupaten Buleleng dan Rumah Sakit Kertha Usada. Selain itu penelitian ini juga bertujuan untuk mengetahui perbedaan kualitas pelayanan BPJS pada pasien rawat inap kelas III pada kedua rumah sakit tersebut. Dalam penelitian ini hanya menggunakan sampel karena populasi yang digunakan berbeda antara Rumah Sakit Umum Daerah Kabupaten Buleleng dan Rumah Sakit Kertha Usada, sehingga hanya menggunakan sampel insidental. Metode yang digunakan dalam penelitian ini adalah metode deskriptif komperatif dengan pendekatan kuantitatif. Teknik pengumpulan data yang dilakukan dalam penelitian ini adalah menggunakan kuesioner. Analisis yang digunakan dalam penelitian ini adalah Analisis Statistik Komparatif, analisis ini dimaksudkan untuk menguji apakah ada perbedaan yang signifikan mengenai kualitas pelayanan BPJS pada pasien rawat inap kelas III di Rumah Sakit Umum Daerah Kabupaten Buleleng dan Rumah Sakit Kertha Usada. Alat yang digunakan untuk mengetahui perbedaan analisis perbandingan rata-rata (Independent-Sample T-Test). Dihitung dengan menggunakan program SPSS 16.00 for windows. Hasil dari penelitian ini yaitu adanya perbedaan yang signifikan antara kualitas pelayanan BPJS pada rawat inap kelas III di Rumah Sakit Umum Daerah Kabupaten Buleleng dengan Rumah Sakit Kertha Usada yang dapat dilihat dari nilai signifikan sebesar $0,027<0,05$. Dari skor rata-rata yang diperoleh, kualitas pelayanan di Rumah Sakit Umum Daerah Kabupaten Buleleng lebih unggul dari pada kualitas pelayanan di Rumah Sakit Kertha Usada.
\end{abstract}

Kata kunci : Kualitas Pelayanan, BPJS

\begin{abstract}
This study is aimed to determine the quality of BPJS service in inpatient class III at General Hospital of Buleleng District and Kertha Usada Hospital. Besides that, this study is also aimed to determine the different quality of BPJS service between the inpatient classes III in those two hospitals mentioned. This study only used incidental sample since the population was different between the population at General Hospital of Buleleng District and Kertha Usada Hospital. The method used was descriptive comparative method with qualitative approach. The data collection technique in this study was using questionnaire. The analysis used was Statistics Comparative Analysis, which intended to examine whether there was significant distinction about the quality of BPJS service in inpatient class III at General Hospital of Buleleng District and Kertha Usada Hospital. The tool which used to find out the difference in average comparison analysis was counted by SPSS 16.00 for Windows Program. The result of the study showed that there is a significant difference between the quality of BPJS service in inpatient class III at General Hospital of
\end{abstract}




\begin{abstract}
Buleleng District and Kertha Usada Hospital in which shown by the significant value obtained $0,027<0,05$. From the average score obtained, the quality of BPJS service in General Hospital of Buleleng District was better than the quality of BPJS service in Kertha Usada Hospital.
\end{abstract}

Keywords: The Service Quality, BPJS

\section{PENDAHULUAN}

Industri jasa kesehatan memiliki prospek yang cukup bagus, karena pelayanan kesehatan tidak terpaku hanya pada pengobatan penyakit tetapi juga memberikan kualitas pelayanan yang maksimal untuk usaha pencegahan penyakit dan meningkatkan kesehatan. Kualitas Pelayanan sebagai suatu tindakan seseorang terhadap orang lain melalui penyajian produk atau jasa sesuai dengan ukuran yang berlaku pada produk atau jasa tersebut untuk memenuhi kebutuhan, keinginan dan harapan orang yang dilayani, (Sugiarto \& Harijono 2000:36).

BPJS kesehatan hadir sebagai sebuah badan hukum pemerintah yang memiliki tugas khusus yaitu menyelenggarakan jaminan pemeliharaan kesehatan bagi seluruh rakyat Indonesia. Terutama untuk Pegawai Negeri Sipil, Penerima Pensiun PNS dan TNI/POLRI, Veteran, Perintis Kemerdekaan beserta keluarganya dan Badan Usaha lainnya ataupun rakyat biasa dan bertujuan untuk mewujudkan terselenggaranya pemberian jaminan kesehatan yang layak bagi setiap peserta atau anggota keluarganya.

Badan publik ini terbentuk berdasarkan hasil transformasi dari PT Askes (Persero) yang pelaksanaannya mulai diberlakukan pada tanggal 1 Januari 2014. Jaminan sosial adalah perlindungan yang diberikan oleh masyarakat bagi anggota-anggotanya untuk resiko-resiko atau peristiwa-peristiwa tertentu dengan tujuan, sejauh mungkin, untuk menghindari peristiwa-peristiwa tersebut yang dapat mengakibatkan hilangnya atau turunnya sebagian besar penghasilan tersebut, dan untuk memberikan pelayanan medis atau jaminan keuangan terhadap konsekuensi ekonomi dan terjadinya peristiwa tersebut, serta jaminan untuk tunjangan keluarga dan anak (Zaeni, 2007).

Badan Penyelenggara Jaminan Sosial (BPJS) merupakan lembaga penyelenggara jaminan sosial sehingga dengan adanya jaminan sosial, resiko keuangan yang dihadapi seseorang, baik itu karena memasuki usia produktif mengalami sakit, mengalami kecelakaan, dan bahkan kematian, akan diambil alih oleh lembaga yang menyelenggarakan jaminan sosial. Dari tahun ke tahun jumlah peserta BPJS Kesehatan selalu mengalami peningkatan dan menandakan bahwa masyarakat saat ini mulai menyadari akan pentingnya pemeliharaan kesehatan. Tingginya animo masyarakat terhadap kebijakan ini juga diiringi dengan fasilitas kesehatan (fakses). Untuk mengatur mekanisme penyelenggaraan, kementerian kesehatan kemudian mengeluarkan Perarutan Menteri Kesehatan Nomor 71 Tahun 2013 Tentang Pelayanan Kesehatan pada Jaminan Kesehatan Nasioanl dan Peraturan Menteri Kesehatan Nomor 28 Tahun 2014 Tentang Pedoman Pelaksanaan Program Jaminan Kesehatan Nasional.

Dengan dikeluarkannya peraturan ini, otomatis seluruh fakses mulai dari Fasilitas Kesehatan Tingkat Pertama (FKTP) hingga Fasilitas Kesehatan Rujukan Tingkat Lanjutan (FKRTL), memiliki acuan atau pedoman yang jelas dalam menyelenggarakan Pelayanan BPJS Kesehatan. Salah satu akses yang menjadi penyelenggara dari kebijakan adalah rumah sakit. Rumah sakit merupakan suatu institusi yang memberikan pelayanan kesehatan semua jenis penyakit dari yang bersifat dasar sampai spesialitik dan mempunyai karakteristik pelayanan yang berbeda dengan industri jasa lainnya. Keberadaan rumah sakit di Bali saat ini sudah semakin banyak, hal ini mengakibatkan semakin 
tingginya tuntutan masyarakat akan fasilitas kesehatan yang berkualitas dengan biaya yang terjangkau. Berbagai upaya telah dilakukan dalam rangka memenuhi harapan-harapan tersebut dengan meningkatkan mutu dan pelayanan rumah sakit dalam upaya untuk memenuhi kebutuhan dan kepuasan pelanggan yaitu pasien di rumah sakit tersebut. Sehingga kepuasan pelanggan tampaknya menjadi parameter kualitas pelayanan suatu rumah sakit. Kualitas pelayanan berpusat pada upaya pemenuhan kebutuhan dan keinginan pelanggan serta ketepatan penyampaian untuk mengimbangi harapan pelanggan.

Keberadaan rumah sakit sebagai mitra dari BPJS Kesehatan merupakan fokus utama penelitian. Karena salah satu fasilitas kesehatan (fakses) yang banyak dikunjungi oleh peserta BPJS Kesehatan adalah rumah sakit. Rumah sakit sebagai salah satu fasilitas pelayanan kesehatan diharapkan dapat memberikan kualitas pelayanan yang efektif terhadap pasien sehingga dapat menciptakan kepuasan tersendiri bagi pasien sebagai pelanggan. Dalam penyelenggaraan pelayanan kesehatan publik oleh rumah sakit yang menjadi mitra BPJS, nyatanya masih banyak dijumpai kekurangan yang mempengaruhi kualitas pelayanan kepada masyarakat. Pelayanan merupakan masalah yang paling banyak dikeluhkan peserta maupun penyedia jasa pelayanan kesehatan.

Dari sisi pasien, sering kali terdengar keluhan bahwa pasien yang menggunakan BPJS mendapatkan pelayanan yang kurang menyenangkan. Ketidak mengertiannya tentang jenis penyakit, informasi mengenai pemeriksaan yang sudah dilakukan dan juga cara mendapatkan obat serta cara mengkonsumsinya menyebabkan mereka sedikit mengeluh.

Tidak hanya dalam bidang perawatan kesehatan, beberapa diantara pasien juga terkadang mengeluh keterlambatan proses administrasi dan juga fasilitas rumah sakit itu sendiri. Beberpa keluhan pasien terhadap kualitas pelayanan BPJS di rumah sakit diantaranya yaitu, sulitnya mendapatkan fasilitas serta susahnya urusan administrasi saat berobat dan juga penolakan pasien atau peserta BPJS dengan alasan kamar penuh. Selain itu pasien juga banyak yang mengeluh akibat pemeriksaan yang dilakukan terburu-buru dan diobati seadanya dan tak jarang pula, pasien masih harus mengeluarkan sejumlah uang karena obat tertentu tidak di-cover oleh BPJS Kesehatan. Jika kondisi ini tidak direspon maka akan menimbulkan citra yang kurang baik terhadap rumah sakit sendiri.

Rumah Sakit Umum Daerah Kabupaten Buleleng dan Rumah Sakit Kertha Usada merupakan rumah sakit yang melayani program BPJS di Kabupaten Buleleng. Rumah Sakit Umum Daerah Kabupaten Buleleng dan Rumah Sakit Kertha Usada melayani pasien dengan rawat inap. Pada instalasi rawat inap di Rumah Sakit Umum Daerah Kabupaten Buleleng berjumlah 56 pasien dengan fasilitas lemari dan kipas angina, sedangkan di Rumah Sakit Kertha Usada pasien berjumlah 36 pasien dengan fasilitas kursi penunggu, sehingga total dari jumlah pasien kedua rumah sakit yang berobat sebanyak 92 pasien, hal ini menyebabkan terjadinya kesibukan bagi perawat, dokter dan karyawan lain.

Salah satu upaya Rumah Sakit Umum Daerah Kabupaten Buleleng dan Rumah Sakit Kertha Usada untuk meningkatkan kualitas pelayanan adalah dengan mengadakan penelitian akan pentingnya kualitas pelayanan oleh pelanggan yang berdasarkan pada dimensi kualitas pelayanan tangibles (bukti langsung), reliability (kehandalan), responsiveness (daya tanggap), assurance (jamianan), dan empathy (empati). (Arief, 2007:118) mengungkapkan bahwa pengertian kualitas pelayanan sebagai tingkat kesempurnaan yang diharapkan dan pengendalian akan kesempurnaan tersebut untuk memenuhi keinginan pelanggan.

Mengukur kualitas pelayanan berarti membandingkan kinerja suatu pelayanan atau jasa dengan seperangkat standar yang telah ditetapkan terlebih dahulu. Salah satu pendekatan kualitas 
pelayanan yang banyak dijadikan acuan dalam riset pemasaran adalah model servqual (service quality). Servqual dibangun atas adanya perbandingan dua faktor utama yaitu persepsi pelanggan atau layanan yang nyata mereka terima (perceived service) dengan layanan sesungguhnya diharapkan/ diinginkan (expected service).

Kualitas pelayanan sering menjadi pokok pembicaraan orang dalam hal pemuasan kebutuhan. Banyak para ahli telah memberikan definisi tentang kualitas pelayanan dengan ungkapan yang berbeda-beda, tetapi yang terkandung didalamnya adalah sama yaitu kualitas pelayanan pada dasarnya meliputi upaya memenuhi harapan pelanggan sesuai dengan spesifikasinya. Kualitas Pelayanan menurut Sugiarto (2000:36) "Sebagai suatu tindakan seseorang terhadap orang lain melalui penyajian produk atau jasa sesuai dengan ukuran yang berlaku pada produk atau jasa tersebut untuk memenuhi kebutuhan, keinginan dan harapan orang yang dilayani".

Menurut Tjiptono (2007:59) "kualitas pelayanan adalah tingkat keunggulan yang diharapkan dan pengendalian atas tingkat keunggulan tersebut untuk memenuhi keinginan pelanggan". Selanjutnya menurut American Socienty for Quality Control (dalam Lupiyoadi, 2001:144), kualitas merupakan keseluruhan ciri-ciri dan karakteristik-karakteristik dari suatu produk/ jasa dalam hal kemampuannya untuk memenuhi kebutuhan-kebutuhan yang telah ditentukan atau bersifat laten. Menurut Kotler \& Keller (2007) dimensi kualitas pelayanan dapat didefinisikan melalui pertama bukti fisik (tangibles), kedua keadaan (reliability), ketiga daya tanggap (responsiveness), keempat jaminan (assurance) dan kelima empati (empathy).

\section{Pembicaraan}

mengenai karakteristik pelayanan akan lebih terfokus pada core business dari berbagai usaha bidang jasa pelayanan "Karakteristik industri jasa pelayanan tersebut antara lain pelayanan rumah sakit, perbankkan, jasa boga, butik, pasa swalayan, pelayanan kantor pos, salon kecantikan, pusat kebugaran, jasa periklanan, retail, pertokoan, perhotelan, show-room, pengantaran barang dan transportasi" (Sugiarto, 2002:46).

Menurut Sugiarto (2002) terdapat sejumlah kriteria yang mencirikan pelayanan atau jasa sekaligus membedakan dari barang, yaitu, pelayanan merupakan output tak berbentuk (intangible output), pelayanan merupakan output variabel, tidak standar, pelayanan tidak dapat disimpan, tetapi dapat dikonsumsi dalam produksi, terdapat hubungan langsung yang erat dengan pelanggan melalui proses pelayanan, pelanggan berpartisipasi dalam memberikan pelayanan, keterampilan personal "diserahkan" atau diberikan secara langsung kepada pelanggan, pelayanan tidak dapat diproduksi secara missal, membutuhkan pertimbangan pribadi yang tinggi dari individu yang memberikan pelayanan, perusahaan jasa pada umumnya bersifat padat kerja, fasilitas pelayanan berada dekat lokasi pelanggan pengukuran efektivitas pelanggan bersifat subyektif, pengendalian kualitas terutama dibatasi pada pengendalian proses. Option penetapan harga lebih rumit. Menurut Gronroos (2001) menyatakan bahwa model pengukuran kualitas pelayanan dengan membandingkan pelayanan yang diharapkan (expected service) dan pelayanan yang dirasakan (perceived service) oleh pelanggan merupakan pengukuran yang asli. SERVQUAL (Services Quality) telah terbukti menjadi modal yang telah banyak digunakan dalam berbagai organisisasi dan industry untuk mengukur kualitas pelayanan termasuk bank (Siddiqi, 2011 \& Lymperopoulos et al., 2006).

Pengukuran kualitas pelayanan dengan model perbandingan tersebut juga didukung oleh Fitzsimmons \& Fitzsimmons (2006:131) mengukur kualitas pelayanan merupakan sebuah tantangan karena kepuasan dipengaruhi oleh banyak hal tidak berwujud (intangible). Perceived service adalah jasa yang dirasakan berdasarkan persepsi 
pelanggan, untuk menghasilkan suatu pelayanan yang berkualitas suatu perusahaan diharapkan dapat mengukur pelayanan yang telah diberikan kepada pelanggannya dengan skala pengukuran yang telah dihasilkan, dalam hal ini servqual memiliki aplikasi skala pengukuran yang disebut multiple-item scale yang merupakan hasil penelitian Parasuraman dkk. Skala dengan validitas dan reliabilitas yang baik tersebut dipergunakan perusahaan untuk dapat dimengerti lebih baik harapan dan persepsi pelanggan akan pelayanan yang diinginkan, yang dapat menghasilkan peningkatan pelayanan.

Penelitian relevan yang dijadikan refrensi dalam penelitian ini adalah penelitian oleh I Gusti Ayu Ngurah Welastri Putri yang berjudul 'Analisis Kualitas Pelayanan pada Instalasi Rawat Inap Rumah Sakit Umum Kertha Usada Singaraja". Penelitian ini bertujuan untuk mengetahui: harapan pelanggan terhadap pelayanan Instalasi Rawat Inap Rumah Sakit Umum Kertha Usada Singaraja, perasaan pelanggan terhadap pelayanan pada Instalasi Rawat Inap Rumah Sakit Umum Kertha Usada Singaraja, kualitas pelayanan pada Instalasi Rawat Inap Rumah Sakit Umum Kertha Usada Singaraja. Penelitian menggunakan desain penelitian deskriptif. Sebjuek penelitian ini adalah pelanggan atau pasien pada Instalasi Rawat Inap Rumah Sakit Umum Kertha Usada Singaraja. Pengumpulan data dalam penelitian ini dilakukan dengan metode kuesioner (angket). Data yang dikumpulkan, dianalisis dengan analisis deskriptifkuantitatif.

\section{METODE}

Penelitian ini dilakukan di Rumah Sakit Umum Daerah Kabupaten Buleleng dan Rumah Sakit Kertha Usada dengan fokus pengamatan pada perbedaan kualitas pelayanan BPJS pada pasien rawat inap pada kelas III. Metode yang digunakan dalam penelitian ini adalah metode deskriptif komperatif dengan pendekatan kuantitatif, yaitu penelitian ini menggambarkan atau menerangkan gejala dari variabel-variabel yang digunakan untuk mengetahui perbedaan. Tahap-tahap dalam penelitian ini diawali dengan merumuskan suatu masalah, mencari teori, menemukan jawaban teoritis, pengumpulan data, mengelola data, dan menarik kesimpulan. Menurut Nazir (2005) "penelitian komperatif merupakan sejenis penelitian deskriptif yang ingin mencari jawaban secara mendasar tentang sebab-akibat, dengan menganalisis faktor-faktor penyebab terjadinya ataupun munculnya suatu fenomena tertentu".

Penelitian ini merupakan penelitian yang menggunakan kuesioner untuk mendapatkan data yang diperlukan, oleh karena itu masing-masing dimensi penelitian perlu dijabarkan dalam indikator-indikator yang akan menjadi pernyataan kepada responden dalam penelitian ini. Menurut Kotler Keller (2007) terdapat lima dimensi pada kualitas pelayanan yaitu tampilan fisik (tengiable), kehandalan (reliability), daya tangkap (responsiveness), jaminan (assurance), dan empati (empathy).

Dalam penelitian ini hanya menggunakan sampel karena populasi yang digunakan berbeda antara Rumah Sakit Umum Daerah Kabupaten Buleleng dan Rumah Sakit Kertha Usada, sehingga hanya menggunakan sampel incidental. Teknik sampling yang digunakan dalam penelitian ini adalah sampling incidental. Menurut Sugiyono (2014) sampling incidental adalah teknik penentuan sampel didasarkan kebetulan, yaitu siapa saja yang secara kebetulan/incidental bertemu dengan peneliti dapat digunakan sebagai sampel, bila dipandang orang yang kebetulan ditemui itu cocok sebagai sumber data. Karena dalam penelitian ini sulit untuk mengetahui jumlah populasi yang menjadi pengunjung, dalam teknik incidental sampling, penentuan sampel berdasarkan kebetulan, yaitu siapa saja yang secara kebetulan/incidental bertemu dengan peneliti dapat digunakan sebagai sampel. Bila dipandang orang yang kebetulan ditemui itu cocok sebagai sumber data.

Ditinjau dari sifatnya, jenis data yang digunakan dalam penelitian ini adalah data kuantitatif. Data yang 
dimaksud adalah data tentang kualitas pelayanan BPJS pada pasien rawat inap berdasarkan kelas III. Ditinjau dari sumbernya, data yang dipergunakan dalam penelitian ini menggunakan 2 jenis data yaitu data skunder yang berupa dokumen-dokumen, catatan/arsip yang dimiliki oleh Rumah Sakit Umum Daerah Buleleng dan Rumah Sakit Kertha Usada dan data primer yang berupa data hasil kuisioner.

Adapun metode pengumpulan data yang dipergunakan dalam penelitian ini adalah dokumentasi, digunakan untuk mencari data dengan memanfaatkan dokumen-dokumen atau arsip-arsip dari jumlah pasien yang terkait dengan masalah yang akan diteliti berupa hasil dari kualitas pelayanan BPJS yang dilakukan. Teknik pengumpulan data yang dilakukan dalam penelitian ini adalah menggunakan kuesioner. Kuesioner ini menggunakan skala likert.

Analisis yang digunakan dalam penelitian ini adalah Analisis Statistik Komparatif, analisis ini dimaksudkan untuk menguji apakah ada perbedaan yang signifikan mengenai kualitas pelayanan BPJS pada pasien rawat inap kelas III di Rumah Sakit Umum Daerah Kabupaten Buleleng dan Rumah Sakit Kertha Usada. Sebagai alat yang digunakan adanya perbedaan digunakan perbedaan analisis perbandingan rata-rata (Independent-Sample T-Test), yaitu analisis yang digunakan untuk membandingkan dua rata-rata dua group yang tidak saling berhubungan dan dihitung dengan menggunakan program SPSS 16.00 for windows (Wahyono, 2009). Dengan menggunakan statistik uji t, statistik uji $t$ digunakan sebagai perbandingan dua atau lebih kelompok sampel data.

Analisis data dalam penelitian ini melalui beberapa tahap yaitu menentukan jumlah skor dari masing-masing dimensi yang diperoleh dari data tabulasi yang telah dilakukan terhadap hasil penyebaran kuesioner kualitas pelayanan yang terdiri dari kuesioner harapan dan perasaan pasien Rumah Sakit Umum Daerah Kabupaten Buleleng dan Rumah Sakit Kertha Usada yaitu pertama, menentukan skor tertinggi dan skor terendah dari keseluruhan alternatif jawaban

$\mathrm{STT}=5 \times$ item pertanyaan $\times \mathrm{n}$

$\mathrm{STR}=1 \mathrm{x}$ item pertanyaan $\mathrm{x} n$

Keterangan:

STT = Skor Tertinggi

STR = Skor Terendah

$\mathrm{n} \quad=$ jumlah responden $=36$

Menentukan interval/rentang dengan ketentuan sebagai berikut:

Interval $=\frac{\text { skor tertinggi-skor terendah }}{\text { kategori }}$

Kategori untuk harapan pasien ada 5 yaitu:

Tabel 1. Kategori Harapan Pasien

\begin{tabular}{lc}
\hline Kategori & Skor \\
\hline Sangat penting & 5 \\
Penting & 4 \\
Kurang penting & 3 \\
Tidak penting & 2 \\
Sangat tidak penting & 1 \\
\hline
\end{tabular}

Kategori untuk perasaan pasien ada 5 yaitu:

Tabel 2. Kategori Perasaan Pasien

\begin{tabular}{lc}
\hline Kategori & Skor \\
\hline Sangat baik & 5 \\
Baik & 4 \\
Kurang baik & 3 \\
Tidak baik & 2 \\
Sangat tidak baik & 1 \\
\hline
\end{tabular}

Menentukan skor kualitas pelayanan dengan rumus.

Kualitas

Pelayanan $=\frac{\text { pelayanan yang dirasakan }}{\text { petayananyang diharapkan }}$

Langkah terakhir menganalisis dan menginterprestasikan hasil pengolahan data untuk selanjutnya dideskripsikan.

\section{HASIL DAN PEMBAHASAN Hasil}

Kualitas pelayanan dapat diukur dengan cara membandingkan dua faktor utama yaitu presepsi pengguna atas pelayanan yang nyata mereka terima (perceived service) dengan pelayanan 
yang sesungguhnya diharapkan atau diinginkan (expected service) di Rumah Sakit Umum Daerah Kabupaten Buleleng dan Rumah Sakit Kertha Usada..
Hasil penelitian mengenai BPJS Pada Pasien Rawat Inap Kelas III di Rumah Sakit Umum Daerah Kabupaten Buleleng dapat dilihat pada tabel 3 di bawah ini.

Tabel 3. Kualitas Pelayanan BPJS Pada Pasien Rawat Inap Kelas III di Rumah Sakit Umum Daerah Kabupaten Buleleng

\begin{tabular}{lrlrcrcr}
\hline \multirow{2}{*}{ Dimensi } & \multicolumn{3}{c}{ Harapan } & \multicolumn{2}{c}{ Perasaan } & & \multicolumn{2}{c}{ Kualitas Layanan } \\
\cline { 2 - 4 } \cline { 6 - 7 } & Skor & Kategori & Skor & Kategori & & Skor & Kategori \\
\hline Tangiable & 657 & Sangat Penting & 649 & Sangat Baik & & 0,99 & Sangat Baik \\
Reliability & 658 & Sangat Penting & 644 & Sangat Baik & & 0,98 & Sangat Baik \\
Responsiveness & 540 & Sangat Penting & 539 & Baik & 0,99 & Sangat Baik \\
Assurance & 649 & Sangat Penting & 648 & Sangat Baik & & 0,99 & Sangat Baik \\
Empathy & 650 & Sangat Penting & 647 & Sangat Baik & & 0,99 & Sangat Baik \\
\hline
\end{tabular}

Sumber: Hasil Perbandingan Pengolahan Data Harapan dan Perasaan Pasien Rumah Sakit Umum Daerah Kabupaten Buleleng.

Fakta pada tabel 3. menyatakan bahwa kualitas pelayanan yang diberikan oleh Rumah Sakit Umum Daerah Kabupaten Buleleng menunjukan bahwa kualitas pelayanan sangat baik. Hasil presentase pada tabel 3. di atas menunjukan bahwa perasaan dan harapan pasien terhadap pelayanan di Rumah Sakit Umum Daerah Kabupaten Buleleng untuk dimensi: Tangiable dengan skor kualitas pelayanan 0,99 dalam kategori sangat baik; Reliability dengan skor kualitas pelayanan 0,98 dalam kategori sangat baik; Responsiveness dengan skor kualitas pelayanan 0,99 dalam kategori sangat baik; Assurance dengan dengan skor 0,99 dalam kategori sangat baik; dan Empathy dengan skor kualitas pelayanan 0,99 dalam kategori sangat baik. Sedangkan hasil penelitian mengenai kualitas pelayanan BPJS pada pasien rawat inap kelas III di Rumah Sakit Kertha Usada dapat dilihat pada tabel 4 di bawah ini.

Tabel 4. Kualitas Pelayanan BPJS Pada Pasien Rawat Inap Kelas III di Rumah Sakit Kertha Usada

\begin{tabular}{|c|c|c|c|c|c|c|}
\hline \multirow{2}{*}{ Dimensi } & \multicolumn{2}{|r|}{ Harapan } & \multicolumn{2}{|c|}{ Perasaan } & \multicolumn{2}{|c|}{ Kualitas Layanan } \\
\hline & Skor & Kategori & Skor & Kategori & Skor & Kategori \\
\hline Tangiable & 588 & Penting & 558 & Baik & 0,95 & Sangat Baik \\
\hline Reliability & 579 & Penting & 565 & Baik & 0,98 & Sangat Baik \\
\hline Responsiveness & 537 & Sangat Penting & 532 & Baik & 0,98 & Sangat Baik \\
\hline Assurance & 568 & Penting & 457 & Baik & 0,80 & Baik \\
\hline Empathy & 591 & Penting & 474 & Baik & 0,80 & Baik \\
\hline
\end{tabular}

Sumber : Hasil Perbandingan Pengolahan Data Harapan dan Perasaan Pasien

Rumah Sakit Kertha Usada

Fakta pada Tabel 4. menyatakan bahwa kualitas pelayanan yang diberikan oleh Rumah Sakit Kertha Usada per dimensi adalah dimensi Tangiable dengan skor kualitas pelayanan sebesar 0,95, Reliability dengan skor kualitas pelayanan sebesar 0,98, Responsiveness dengan skor kualitas pelayanan sebesar 0,98 dalam kategori sangat baik, dimensi
Empathy dengan skor kualitas pelayanan sebesar 0,80, dan Assurance dengan skor kualitas pelayanan sebesar 0,80 menunjukan bahwa kualitas pelayanan dalam kategori baik. Sehingga Perbedaan Kualitas Pelayanan BPJS Kelas III di Rumah Sakit Umum Daerah Kabupaten Buleleng dengan Rumah Sakit Kertha Usada dapat dilihat pada tabel 5 berikut. 
Tabel 5. Group Statistics

\begin{tabular}{|c|c|c|}
\hline & Kelompok & $\mathrm{N}$ \\
\hline \multirow[t]{2}{*}{ Nilai } & RSUD & \\
\hline & RSKU & \\
\hline
\end{tabular}

Dari perhitungan pada tabel 5 kerja $\overline{d i}$ atas, dapat diperoleh hasil penelitian bahwa besarnya rata-rata kualitas pelayanan BPJS kelas III pada Rumah

\begin{tabular}{rrr}
\hline Mean & Std. Deviation & Std. Error Mean \\
\hline .9928 & .03874 & .00646 \\
.9050 & .06050 & .01008 \\
\hline
\end{tabular}

Sakit Umum Daerah Kabupaten Buleleng adalah sebesar 0,99 dan kualitas pelayanan BPJS kelas III pada Rumah Sakit Kertha Usada sebesar 0,90.

Tabel 6. Independent Samples Test

Levene's
$\begin{gathered}\text { Test for } \\ \text { Equality of } \\ \text { Variances }\end{gathered}$


p-ISSN : 2599-1418

e-ISSN : 2599-1426

dan meringankan beban biaya bagi kalangan tidak mampu..

$$
\text { Untuk itu pelayanan di Rumah }
$$

Sakit bisa ditingkatkan kualitas pelayanannya dengan memperhatikan unsur-unsur pelayanan yang berkualitas yang terdiri dari dua dimensi yang integral, yaitu dimensi prosedural yang bersifat sistematis dan berkaitan dengan sistem penyajian layanan yang mencakup bagaimana sebaiknya pelayanan tersebut didesain dan bahgaimana prosedur dalam melakukan segala sesuatu.

Dimensi ini terdiri dari beberapa standar yang perlu diperhatikan dalam memberikan pelayanan yang berkualitas seperti pemilihan waktu, arus, fleksibilitas, antisipasi, komunikasi, umpan balik pelanggan, organisasi dan Supervise serta dimensi personal lebih bersifat interpersonal dan meliputi pola-pola sikap, prilaku dan keterampilan verbal yang ada dalam setiap interaksi layanan personal. Dalam dimensi ini terdiri dari beberapa standar yang perlu diperhatikan dalam memberikan pelayanan yang berkualitas seperti penampilan, bahasa tubuh dan nada suara, perhatian, berakal budi, panduan, keterampilan menjual, pemecahan masalah dengan ramah.

\section{SIMPULAN DAN SARAN Simpulan}

Berdasarkan hasil penelitian dan pembahasan, maka dapat disimpulkan bahwa kualitas pelayanan yang diberikan oleh Rumah Sakit Umum Daerah Kabupaten Buleleng dilihat dari masingmasing dimensi berada pada kategori sangat baik, kualitas pelayanan yang diberikan oleh Rumah Sakit Kertha Usada dilihat dari dimensi Tangiable, Reliabillity, Respontsiveness juga berada pada kategori sangat baik namun terdapat dimensi yang berada pada kategori baik yaitu dimensi Assurance dan Empathy. Dilihat dari hasil temuan tersebut maka dapat disimpulkan bahwa terdapat perbedaan yang signifikan dari kualitas pelayanan BPJS pada pasien rawat inap kelas III di Rumah Sakit Umum Daerah Kabupaten Buleleng dengan Rumah Sakit Kertha Usada. Hasil penelitian pelayanan
Jurnal Pendidikan Ekonomi Undiksha

Volume 10 No. 1 Tahun 2018

yang dirasakan atau yang diterima oleh pasien lebih rendah dari yang diharapkan oleh pasien itu sendiri.

\section{Saran}

Berdasarkan hasil penelitian yang telah disimpulkan di atas, peneliti dapat memberikan saran untuk rumah sakit agar meningkatkan kualitas pelayanan yang dilihat dari dimensi Assurance dan Empathy agar apa yang diharapkan dan dirasakan pasien dari kualitas pelayanan Rumah Sakit dapat terwujud dan untuk peneliti selanjutnya hendaknya lebih memperluas lagi penelitian tentang Kualitas Pelayanan BPJS di Rumah Sakit dan memperluas wilayah penelitian karena semakin luas wilayah penelitian maka akan didapatkan hasil yang lebih kongkrit dari suatu wilayah.

\section{DAFTAR PUSTAKA}

Arief. 2007. Pemaparan Jasa \& Kualitas Pelayanan. Malang: Bayumedia Publishing.

Fitzsimmons, James A, \& Mona J. Fitzsimmons. $2006 \quad$ Service Management (Operation, strategy, and Information Technology). Boston: The McGra-Hill Companies Inc.

Gronroos, Cristian, 2001. Service Management and Marketing, A Costume Relationship Management Approach, New York; Jhon Wiley and Sons.

Kotler, P. dan Keller, K.L. 2007. Manajemen Pemasaran. Jilid 1 dan 2. Jakarta: PT Indeks.

Lupiyoadi, Rambat. 2001. Manajemen Pemasaran Jasa. Jakarta: PT Salemba Empat.

Lymperopoulus, Constantine. 2006. The Importance of Service Quality in Bank Selection For Mortgage Loans. Jurnal Management, 16 (4) 365-379.

Mohammad Nazir, 2005. Metode Penelitian. Jakarta: Ghalia Indonesia 
Sugiarto \& Harijono. 2000. Peramalan Bisnis. Jakarta: PT. Gramedia Pusaka Utama.

Sugiarto, Endar. 2002. Psikologi Pelayanan Dalam Industri Jasa. Jakarta: PT Gramedia Pustaka Utama.

Sugiyono. 2009. Statistika Untuk Penelitian. Edisi Kesembilan belas. Jakarta: Alfabeta.

Siddiqi, KO. 2011. Between Service Quality Attributes, Cutoer Satisfication and Costumer Loyality in the Retail Banking Sector in Bangladesh, International Journal of Business and Managemen, Vol. 6, No. 3, pp. 1236.

Tjiptono, Fandy. 2007. Strategi Pemasaran. Edisi Kedua. Yogyakarta: Andi.

Wahyono, Teguh. 2013. .25 Model Analisis Statistik dengan SPSS 17: Memahami Teknik Analisis Statisti Secara Sistematis dan Praktis. Jakarta: PT.Elex Media Komputindo.

Welastri Putri, I Gusti Ayu. 2009. Analisis Kualitas Pelayanan Instalasi Rawat Inap Rumah Sakit Umum Kertha Usada Singaraja. Skripsi Sarjana Jurusan Pendidikan Ekonomi Universitas Pendidikan Ganesha.

Zaeni, Asyhadie. 2007. Aspek-Aspek Hukum Jaminan Sosial Tenaga Kerja di Indonesia. Mataram : Rajawali Pers. 